\title{
THE INFLUENCE OF VOCABULARY MASTERY TOWARD ENGLISH SPEAKING ABILITY OF THE FOURTH SEMESTER STUDENTS OF ENGLISH EDUCATION STUDY PROGRAM MUHAMMADIYAH UNIVERSITY
}

\author{
Yasmika Baihaqi \\ Muhammadiyah University of Metro
}

\begin{abstract}
One of the purpose of teaching speaking is the students are able to use English as a means of communication based on the context and situation related to their level of vocabulary mastery. So before we are able to communicate well, we should have a large number of words.

The objective of this research is to find out whether vocabulary is influential toward English speaking ability. The populations of this research are 190 students of all the fourth semester in the academic year of 2009-2010. Based on the table of Krecjie, a number of samples are 127 students. The sampling technique used is the simple random sampling technique. To collect the data, the researcher requires two tests, vocabulary and speaking tests.

This study yields that there is a positive and significant influence between English vocabulary mastery and the students' speaking ability, it is proved by the value of correlation coefficient 0.764 which is higher than the value of $r$ table $(0.176)$. It means that the rise of the independent variable (the students' vocabulary mastery) will be followed by the rise of the dependent variable (English speaking ability). The effective contribution of the students' vocabulary mastery toward English speaking ability is $58.6 \%$
\end{abstract}

Key word: Vocabulary Mastery, Speaking Ability, and Influence

Language is one of the most important things in human life. We cannot imagine what life would be without language. It is impossible to live without it. So, language is very important for us. In daily life, one uses language to express his feeling and to tell something. From the statement above it can be stated how important language, language has function to communicate to other people. Language is one of the most important things in human life. We cannot imagine what life would be without language. It is impossible to live without it.

So, language is very important for us. In daily life, one uses language to express his feeling and to tell something. From the statement above it can be stated how important language, language has function to communicate to other people.

If the student wants to speak English, Students should have many vocabularies, no one who can use speak. Without vocabulary students cannot use speak in
English. So, Students does not have enough confidence to speak and this is related to the learning experience which does not emphasize on the speaking ability. Thus, if student want to speak English they must master vocabulary. So vocabulary is very important and has influence toward speaking ability.

\section{METHODOLOGY}

This research applies quantitative method and intends to find out whether vocabulary mastery is influential toward English speaking ability. The researcher tries to discover the influence of vocabulary mastery toward English speaking ability. First, the researcher gives some test to students to know how far their vocabulary mastery. The second, to do speaking test between the researcher and students and record the conversation. For example, when the researcher and students are communicating, the 
researcher record their conversation so that the researcher can analyze students' speaking ability

The sampling technique used is the simple random sampling technique. To collect the data, the researcher requires two tests, vocabulary and speaking tests. To test the instrument validity, it employs content, construct, and item validities while the reliability of instrument is measured by using Alpha Cronbach formula. The data are analyzed by utilizing descriptive and inferential statistics including normality and linearity test, and also Productmoment and simple regression analysis.

The data analyzed by using qualitative data. The quantitative data was using a simple regression formula to find out the influence of vocabulary mastery toward English speaking ability.

Simple regression is to find the regression equation.

The formula of that is:

$$
\mathbf{Y}=\mathbf{a}+\mathbf{b} \mathbf{X}
$$

\section{The meaning of symbol:}

$\mathrm{Y}$ : Dependent Variable

$\mathrm{X}$ : Independent Variable

a : Constant Number

b : Coefficient of Regression

(Usman and Akbar 1995: 216)

\section{Finding}

The description of two variables would be presented in detail. The mean and the standard deviation of the students' scores are discussed in this part. The researcher utilized the computer program on SPSS (Statistical Package for Social Science) to analyze the data. The result of descriptive analysis could be drawn as follows.
The Summary of the Descriptive Analysis

\begin{tabular}{|c|c|c|}
\hline \multirow[b]{2}{*}{ Description } & \multicolumn{2}{|r|}{ Variables } \\
\hline & $\begin{array}{l}\text { Vocabulary } \\
\text { mastery }\end{array}$ & $\begin{array}{c}\text { English } \\
\text { speaking } \\
\text { ability } \\
\end{array}$ \\
\hline $\begin{array}{l}\text { Number } \\
\text { cases }(\mathrm{N})\end{array}$ & 127 & 127 \\
\hline Mean $(\mathrm{X} \overline{)}$ & 66.57 & 67.23 \\
\hline $\begin{array}{l}\text { Standard } \\
\text { Deviation (SD) }\end{array}$ & 8.68 & 11.05 \\
\hline Minimum Score & 48 & 36 \\
\hline $\begin{array}{l}\text { Maximum } \\
\text { Score }\end{array}$ & 88 & 94 \\
\hline Range & 40 & 58 \\
\hline
\end{tabular}

The result of the descriptive analysis in the vocabulary mastery showed that the minimum score achieved by the students was 48 and the maximum score was 88 so that the range is 40 . The mean and standard deviation were 66.57 and 8.68 respectively. Meanwhile, the number of cases to be analyzed was 127 students.

Furthermore, the result of the descriptive analysis of English speaking ability could be described that the minimum and maximum scores were 36 and 94, the range was 58. The mean was 67.23 and the standard deviation was 11.05. The number of cases is 127 students.

\section{Product moment Analysis}

In order to find out the critical value, the researcher presents the result of Product Moment correlation. In the table of the correlation below, the variable $\mathrm{X}$ is correlated with the variable $\mathrm{Y}$, on the contrary the variable $\mathrm{Y}$ is correlated with the variable $X$.

\section{The Results of Correlation Coefficient by Product Moment Formula}

As visualized in Table 4.3, the correlation matrix value of the independent and dependent variable was 0.764 and it means that there is a positive influence between independent variable and 
dependent one. To prove the hypothesis whether it is accepted or rejected can be conducted by seeing the significance and the correlation coefficient. If the significance is smaller than 0.05 or the value of correlation coefficient $(r)$ is higher than the value of r-table, the hypothesis is accepted.

The value of the correlation coefficient in Table 4.3 is 0.764 which is higher than the value of r-table $0.176(0.764>0.176)$ and the probability is smaller than 0.05 (. It means that there is a significant correlation between vocabulary mastery and speaking ability.

So, if the students master vocabulary, they will have good speaking ability and will be able to speak English fluently. It's proved by there is a significant correlation between vocabulary mastery and speaking ability.

\section{Regression Analysis}

The regression analysis is applied to determine the contribution of the independent variable $(\mathrm{X})$ to the dependent variable (Y). The results of regression analysis are shown in Table

\section{The Summary of Regression Coefficient}

Correlations

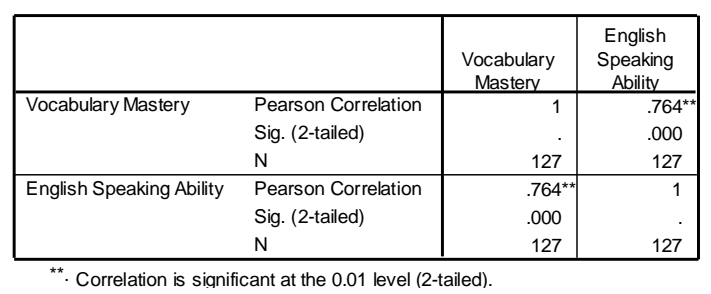

\begin{tabular}{|c|c|c|c|c|}
\hline $\mathbf{R}$ & $\begin{array}{c}\mathbf{R} \\
\text { Square } \\
\left(\mathbf{r}^{2}\right)\end{array}$ & $\begin{array}{c}\text { Std error } \\
\text { estimate }\end{array}$ & $\begin{array}{c}\text { Beta } \\
\mathbf{0}\end{array}$ & $\begin{array}{c}\text { Beta } \\
\mathbf{1}\end{array}$ \\
\hline 0.764 & 0.584 & 7.156 & 0.538 & 0.973 \\
\hline
\end{tabular}

The determination coefficient (R Square) is used to know the effective contribution of the independent variable toward the dependent variable. It is found that the coefficient of determination $\left(\mathrm{R}^{2}\right)$ is 0.584 . It means that the vocabulary mastery as the independent variable (X) has contribution of $58.4 \%$ to the speaking ability as the dependent variable (Y), and $41.6 \%$ is influenced by other factors..

The value of standard estimate is 7.156. The value of beta 0 is 0.538 and beta 1 is 0.973. Therefore; the equation of regression between vocabulary mastery and speaking ability can be arranged as follows:

$$
Y=0.538+0.973 x
$$

The equation of regression that has been found can be utilized to estimate how the influence of independent variable to the dependent variable.

For example, the score of the vocabulary mastery is 50 , so the score of speaking ability is like the following equation:

$$
Y=0.538+(0.973 \times 50)=49.19
$$

Thus the estimation of the speaking ability is 49.19 by adding the vocabulary mastery score in the amount of 50. The regression equation above can be interpreted that if the vocabulary mastery increases 1 point, the speaking ability will increase 0.973 point.

\section{Discussion}

On the basis of the data analysis, it can be seen that the students get the mean score of 66.57 and standard deviation of 8.68 on vocabulary mastery. Then, on speaking ability, the students get the mean score of 67.23 and standard deviation of 11.05. Comparing the result of mean score for both variables (vocabulary mastery and speaking ability), it is clear that there is no significant difference of both variable. Statistically, the score of the students' vocabulary mastery is the same as the score of their speaking ability.

The result of the hypothesis testing shows that there is a positive and significant influence between vocabulary mastery and speaking ability. It is proved by the value 
of the correlation coefficient (r) which is higher than the value of r-table $(0.764>0.176)$ at the significant level of $5 \%$ and $\mathrm{N}=127$. The positive influence means that the higher the student's vocabulary mastery is the higher English speaking ability will be. On the other hand, the lower vocabulary mastery the students get, the lower English speaking ability will be.

The computation of regression formulation shows that $\mathrm{R}$ collective between vocabulary mastery and English speaking ability is 0.584 or R Square is $58.4 \%$. Thus, the effective contribution of the independent variable toward the dependent one is $58.4 \%$. The total influence from all independent variables should be $100 \%$. If $58.4 \%$ of them is affected by vocabulary mastery, consequently, $41.6 \%$ (the products of $100 \%-58.6 \%$ ) of them is resulted from many other independent variables. In addition, based on the score of beta 0 and beta 1 , the regression equation can be drawn as follows:

$$
Y=0.538+0.973 x
$$

This regression equation is useful to predict the English speaking ability based on the scores of the vocabulary mastery. If the scores of the vocabulary mastery changes in one unit of raw score, the variable of speaking ability changes 0.973 .

Thornbury (2005: 1) says that speaking is the process to produce letters, for distinctive vowel, and consonant. In other words, speaking will produce vocabulary and grammar. Thus, without any vocabulary, it is impossible to get good speaking. It is clear that vocabulary will give much contribution to achieve good speaking skill. If the student wants to speak English, they should have vocabularies. When someone has high vocabulary mastery and their speaking ability is low, it is because there are still other factors that have higher influence in developing English speaking ability. Thus, the success of increasing English speaking ability is not only determined by the vocabulary mastery but also other factors.

\section{Conclusion And Suggestion}

The result of descriptive analysis could be described that the mean of the vocabulary mastery is 66.57 and the mean of English speaking ability is 67.23. There is a positive and significant influence between the students' vocabulary mastery and English speaking ability. It is proved by the result of descriptive of analysis that the value of correlation coefficient (0.764) which is higher than the value of $r$ table (0.176). It means that the rise of the independent variable (the students' vocabulary mastery) will be followed by the rise of the dependent variable (English speaking ability).

The effective influence of the students' vocabulary mastery toward English speaking ability is $58.4 \%\left(\left(\mathrm{R}^{2}\right)\right.$. It means that the students' vocabulary mastery gives influence $(58.4 \%)$ to the success of English speaking ability whereas the influence of other factor is $41.6 \%$, but for the other factor the researcher doesn't researches it.

Based on the conclusion, the writer would like to propose some suggestions which will be useful for the lecturers, the students, and other researchers.

The first the writer suggests the student to have good vocabulary mastery since it correlates positively and significantly with English speaking ability. In order to have good vocabulary mastery, the students can enrich their vocabularies through reading English textbooks or other.

The second as the present study shows that English vocabulary mastery has a positive and significant influence with the students' speaking ability, the lecturers of 
English Education Study Program of Muhammadiyah University Metro have to motivate the students to increase their vocabulary mastery through a good method or technique of learning.

The last for other language researchers, this thesis may encourage them to conduct other studies concerning speaking ability. Investigating other affecting factors is really needed to identify the problems to improve the speaking ability to the students.

\section{References}

Arikunto, Suharsimi. 2006. Prof. Dr. Prosedur Pendidikan. Jakarta : Rineka Cipta

Brown, Douglas. 1994. Principles of language learning and teaching. Californnia : San Frasisco State University.

Burton, Barbara, S.MA, 2007. English Grammar Comprehension. Jakarta: PT. Gramedia

Fulcher, Glenn. 2003. Testing Second Language Speaking. Great Britain: Longman.

Linda diamond and Linda Ghulthon. 2006. Teaching Vocabulary. Reading Rocket

Narbuko, Cholid, Drs. 2007. Metodologi Penelitian. Jakarta : Bumi Aksara

Setiyadi, Bambang. 2007. TEFL 2. Jakarta: Universitas Terbuka

Sudjana, 2005. Metoda statistika. Bandung: Tarsito.

Sugiyono. 2009. Metode Penelitian Kuantitatif Kualitatif Dan $R \& D$. Bandung: C.V Alfabeta

Sugiono. 2003. Statistika untuk penelitian. Bandung : CV Alfabeta.

Thornbury, Scoot. 2005. How to Teach Speaking. England : Longman.

Usman, Husaini. 1995. Pengantar Statistika. Jakarta : Bumi Aksara 